\title{
HYDRAZIDE SCHIFF BASES OF ACETYLACETONATE METAL COMPLEXES: SYNTHESIS, SPECTROSCOPIC AND BIOLOGICAL STUDIES
}

\author{
CHARITY W. DIKIO ${ }^{1}$, IKECHUKWU P. EJIDIKE ${ }^{1 *}$, FANYANA M. MTUNZI ${ }^{1}$, MICHAEL J. KLINK² ${ }^{2}$,ZEKIEL D. DIKIO ${ }^{1}$ \\ ${ }^{1}$ Department of Chemistry, Vaal University of Technology, Vanderbijlpark, 1911, South Africa, ${ }^{2}$ Department of Biotechnology, Vaal \\ University of Technology, Vanderbijlpark, 1911, South Africa \\ Email: destinedchild12@gmail.com; ikechukwue@vut.ac.za \\ Received: 24 Aug 2017 Revised and Accepted: 02 Nov 2017
}

\section{ABSTRACT}

Objective: The study was focused on the synthesis and spectroscopic studies of metal acetylacetonates and their complexes using bidentate Schiffbase ligands (NO), evaluation of their in vitro antibacterial potentials against pathogenic microorganism.

Methods: Acetylacetonate salts of Cobalt (II), Manganese (II) and Magnesium (II) were prepared by reacting their metal hydroxides with acetylacetone. The metal complexes of $N^{\prime}-\{(E)$-[4-(diethylamino)-2-hydroxyphenyl] methylidene $\}$-4-nitrobenzohydrazide (HL $\left.{ }^{1}\right)$, $N^{\prime}-\{(E)-[4-$ (diethylamino)-2-hydroxyphenyl] methylidene\}-4-methoxybenzohydrazide ( $\mathrm{HL}^{2}$ ) obtained from the condensation reaction of 4-(diethylamino)-2hydroxybenzaldehyde and 4-nitrobenzohydrazide/or 4-methoxybenzohydrazide. The synthesized compounds were characterized by fourier transform infrared spectroscopy (FT-IR), proton and carbon-13 nuclear magnetic resonance (NMR), thermo gravimetric analysis (TGA). The compounds were screened for antimicrobial properties against a list of Gram-positive bacterial strains.

Results: The FT-IR spectra revealed that the Schiff bases acts as bidentate chelating ligand via a nitrogen of the azomethine and phenolic oxygen atoms. NMR reveals the presence of azomethine $(\mathrm{HC}=\mathrm{N})$ and aromatic hydrogens at expected chemical shifts confirming the formation of the Schiff base ligands. Thermal decomposition behaviour was studied by thermogravimetry revealing stability up to $260{ }^{\circ} \mathrm{C}$. The compounds were evaluated for antibacterial potentials against Staphylococcus aureus and Enterococcus faecalis. The manganese acetylacetonato $\left(N^{\prime}-\{(E)-[4-(\right.$ diethylamino)-2hydroxyphenyl] methylidene\}-4-methoxybenzohydrazide: Mn (acac) ( $\mathrm{L}^{2}$ ) exhibited antimicrobial activities against both Enterococcus faecalis and Staphylococcus aureus with a minimum inhibitory concentration (MIC) of $398.0 \mu \mathrm{g} / \mathrm{ml}$.

Conclusion: The prepared compounds showed no inhibition against the selected pathogenic microorganisms except for Mn(acac)( $\mathrm{L}^{2}$ ). Standard antibacterial compounds: ampicillin and ciprofloxacin was used as positive control. The antibacterial activity of the compound depends on the kind of substituent on the benzo hydrazide rings at the para position, thereby suggesting the compound as promising chemotherapeutic agents for further structural optimization.

Keywords: Metal acetylacetonates, Schiff base complexes, Spectroscopic studies, Thermal studies, Antibacterial

(c) 2017 The Authors. Published by Innovare Academic Sciences Pvt Ltd. This is an open access article under the CC BY license (http://creativecommons.org/licenses/by/4.0/) DOI: http://dx.doi.org/10.22159/ijpps.2017v9i12.22225

\section{INTRODUCTION}

Infectious diseases which are directly related to bacteria exhibiting multiple resistance to antibiotics have increased the world's mortality rate, resulting in about 17 million deaths globally per year in children and the elderly [1]. Therefore, the need to develop novel antibacterial drugs with excellent mechanisms of action and the structural-activity relationship has become an urgent biomedical necessity [2]. Schiff base ligands bearing azomethine $(>\mathrm{C}=\mathrm{N}-$ ) functional group, possessing $\mathrm{N}, \mathrm{O}$, and $\mathrm{S}$-donor atoms have been established as versatile pharmacophores for design and development of various biologically active compounds [3]. They are used in wide variety of applications such as anti-cancer, anti-corrosion, anti-HIV, anti-radical, anti-bacterial and anti-fungal material and DNA cleavage [2, 4]. Some biologically important Schiff base derivatives include the imidazoles, pyrimidines, hydrazides and hydrazine's [5-6]. Hydrazide derivatives have been reported to possess a broad spectrum of antibacterial activities. They also act as a good potential for oral drugs used for the treatment of genetic disorders like thalassemia [7-8].

Schiff bases and their complexes are very attractive materials for several applications due to their desirable features such as structural similarities with natural biological substances, relatively simple preparation procedures, the synthetic flexibility that enables the design of suitable structural properties, selectivity and sensitivity towards the central metal atom rich architectural variety and amazing coordination capacity [9-11]. The chemical stability of Schiff base complexes can be influenced by the presence of azomethine linkage which has a great impact in increasing the basicity of each nitrogen atom [12]. These metal complex derivatives showing considerable biological activity may represent an interesting approach for designing new antibacterial and antifungal drugs [13].

In this study, we describe the synthesis of two hydrazides Schiff base ligands: 4-(diethylamino)-2-hydroxybenzaldehyde with 4-nitrobenzohydrazide or 4-methoxybenzohydrazide and their Mn (acetylacetonate) 2, Co(acetylacetonate) $2, \mathrm{Mg}$ (acetylacetonate) 2 complexes by reflux methods as chemotherapeutic agents with interesting biological properties such as antimicrobial activity. The synthesized compounds were characterized by FT-IR, TGA, ${ }^{1} \mathrm{H}$ NMR and ${ }^{13} \mathrm{C}$ NMR.

\section{MATERIALS AND METHODS}

Experimental

\section{Materials and spectral measurements}

All the chemicals used in this project were of analytical reagent (AR) grade and used as received from the suppliers without further purifications. The chemicals were obtained from different suppliers as indicated. Methanol, dimethyl sulfoxide (DMSO), dimethylformamide (DMF), Hydrogen peroxide $\left(\mathrm{H}_{2} \mathrm{O}_{2}\right)$, distilled acetylacetone, 4methoxbenzhydrazide, 4-(diethylamino)-2-hydroxybenzaldehyde, 4nitrobenzohydrazide, Cobalt(II) acetate tetrahydrate were purchased from Sigma Aldrich, South Africa; Magnesium Chloride Hexahydrate, Potassium permanganate, Potassium Hydroxide and Sodium Hydroxide were purchased from LABCHEM, Gauteng, South Africa. IR spectra were recorded by using a PerkinElmer 580 Spectrometer within the range of $4000-400 \mathrm{~cm}^{-1}$ in nujol mull, METTLER TOLEDO TGA with the top-ofthe-line ultra-micro balance with unique built-in calibration weights for thermo grams and ${ }^{1} \mathrm{H}$ and ${ }^{13} \mathrm{C}$ NMR spectra in $d_{6}$-DMSO solution using 
TMS as an internal standard were obtained with Agilent VnmrJ 3 Spectrometer operating at $500 \mathrm{MHz}$.

\section{General procedure for the synthesis of Schiff base ligands (HL'-} $\mathrm{HL}^{2}$ )

\section{$N^{\prime}$-\{(E)-[4-(diethylamino)-2-hydroxyphenyl]methylidene\}-4- nitro-benzohydrazide (HL)}

The Schiff base ligand was prepared in line with the method described in the literature [14]. Stoichiometric amounts of 4(diethylamino)-2-hydroxybenzaldehyde $(10 \mathrm{mmol})$ in methanol (50 $\mathrm{ml})$ was carefully added to a stirred pre-warmed methanolic solution of 4-nitrobenzohydrazide $(10 \mathrm{mmol})$ and refluxed at $70{ }^{\circ} \mathrm{C}$ for $2 \mathrm{~h}$ in a closed system. Consequently, the resultant mixture was cooled to room temperature and then concentrated to a volume of $20 \mathrm{ml}$. The solid product formed was recovered by filtration, washed with methanol and dried in a desiccator over anhydrous $\mathrm{CaCl}_{2}$. The synthetic pathway of the ligand is explained in scheme 1 .

\section{$N^{\prime}$-\{(E)-[4-(diethylamino)-2-hydroxyphenyl]methylidene\}-4- methoxybenzohydrazide $\left(\mathrm{HL}^{2}\right)$}

The Schiff base ligand was prepared in line with the method described in the literature [14]. Stoichiometric amounts of 4(diethylamino)-2-hydroxybenzaldehyde $(10 \mathrm{mmol})$ in methanol (50 $\mathrm{ml}$ ) was carefully added to a stirred pre-warmed methanolic solution of 4-methoxybenzohydrazide $(10 \mathrm{mmol})$ and refluxed at 70 ${ }^{\circ} \mathrm{C}$ for $2 \mathrm{~h}$ in a closed system. Consequently, the resultant mixture was cooled to room temperature and then concentrated to a volume of $20 \mathrm{ml}$. The solid product formed was recovered by filtration, washed with methanol and dried in a desiccator over anhydrous $\mathrm{CaCl}_{2}$. The synthetic pathway of the ligand is explained in scheme 1.

\section{Synthesis of metal acetylacetonates: M(acac) ${ }_{2}$}

Acetylacetonate salts of Cobalt (Co), Manganese (Mn), and Magnesium $(\mathrm{Mg}$ ) were prepared by reacting their metal hydroxides with acetylacetone [15].

Cobalt acetylacetonate, $\mathrm{Co}(\mathrm{acac})_{2}$ : Cobalt acetate tetrahydrate $(10 \mathrm{~g}$, $40.1 \mathrm{mmol}$ ) was dissolved in $200 \mathrm{ml}$ water in a $500 \mathrm{ml}$ beaker. $\mathrm{KOH}$ $(20 \%)$ was added slowly with constant stirring to precipitate the metal as its hydroxide. Initially, a blue precipitate was formed. The precipitate was stirred for $10 \mathrm{~min}$ and allowed to stand for $30 \mathrm{~min}$. The colour of the precipitate changed from blue to green and finally to pink. The addition of the alkali was continued until the $\mathrm{pH}$ of the solution was raised to 8 . The metal hydroxide formed was repeatedly washed with water to remove all traces of the alkali followed by decantation and finally filtered using Whatman No. 2 filter paper.

The pink cobalt (II) hydroxide was quantitatively transferred into a $250 \mathrm{ml}$ beaker. Distilled acetylacetone $(9.1 \mathrm{ml}, 88.2 \mathrm{mmol})$ was added dropwise with continuous stirring. An exothermic reaction took place leading to the formation of the pink shiny crystalline compound. The crystals were allowed to stand at room temperature for $30 \mathrm{~min}$ and then placed in an ice-water bath for $15 \mathrm{~min}$. The pink shiny crystals of cobalt acetylacetonate formed were filtered. The resulting crystals were separated by filtration, washed and dried in a vacuum desiccator over anhydrous $\mathrm{CaCl}_{2}$ for $48 \mathrm{~h}$.

Manganese acetylacetonate $\mathrm{Mn}(\mathrm{acac})_{2}$ : Following the above procedure, the compound was obtained as dark brown shinny crystals from powdered $\mathrm{KMnO} 4(5.0 \mathrm{~g}, 31.7 \mathrm{mmol})$ dissolved in 100 $\mathrm{ml}$ water and acetylacetone $(14.67 \mathrm{ml}, 147 \mathrm{mmol})$.

Magnesium acetylacetonate $\operatorname{Mg}(\mathrm{acac})_{2}$ : Following the same procedure, the compound was obtained as white crystals from magnesium chloride hexahydrate $(10 \mathrm{~g}, 49.19 \mathrm{mmol})$ dissolved in $200 \mathrm{ml}$ water and acetylacetone $(11.15 \mathrm{ml}, 108.21 \mathrm{mmol})$.

\section{Synthesis of metal schiff base complexes}

In a $250 \mathrm{ml}$ round bottom flask fitted with a water condenser, a warm stirred methanolic solution $(30 \mathrm{ml})$ of the ligands: $\mathrm{HL}^{1}$ or $\mathrm{HL}^{2}$ $(0.01 \mathrm{~mol})$ was mixed with $(0.01 \mathrm{~mol})$ of [Co(acac) 2$] /$ $\left[\mathrm{Mn}(\mathrm{acac})_{2}\right] /\left[\mathrm{Mg}(\mathrm{acac})_{2}\right]$ respectively dissolved in $30 \mathrm{ml}$ methanol in a dropwise manner. The colour of the solutions changed immediately. The mixture was stirred vigorously for $20 \mathrm{~min}$. and refluxed over a steam bath at $70^{\circ} \mathrm{C}$ for $2 \mathrm{~h}$ in a closed. Consequently, the resultant solution was left overnight in a fume cupboard at ambient temperature until all traces of the solvent had evaporated. The solid formed, washed with methanol and dried over anhydrous calcium chloride in a vacuum desiccator. Scheme 2, describes the detailed synthetic pathway for the Schiff base complexes.

\section{Antibacterial assay}

\section{Bacterial strains}

The synthesized Schiff base ligands and their metal complexes were evaluated for their in vitro antibacterial activities. Antibacterial activity was tested against a list of Gram-positive bacterial strains: Staphylococcus aureus and Enterococcus faecalis using a modification of the Kirby-Bauer disc diffusion technique [5]. The micro-organisms were obtained from the Department of Microbiology, North-West University, South African.

A total of ten Staphylococcus aureus: (1R04) S. aureus, (1R06) S. aureus, (1R09) S. aureus, (2R04) S. aureus, (2RO5) S. aureus, (3RO6) S. aureus, (3RO9) S. aureus, (4R4) S. aureus, (4R5) S. aureus and (15Z1) S. aureus and five Enterococcus faecalis: (DEEL4-2) E. faecalis, (STL1-3) E. faecalis, (MP3-1) E. faecalis, (MP3-2) E. faecalis and (V2-2) E. faecalis were used in the study. However, the identities of the isolates used in the study were confirmed using preliminary gram staining, (catalase test, hemolysis on blood agar) and confirmatory serotyping, (specific PCR analysis) and the Matrix-assisted laser desorption/ionization-time of flight (MALDI-TOF) Mass Spectrometry.

\section{In vitro antimicrobial assay}

The synthesized compounds were tested to evaluate their growth inhibitory activities against the selected bacteria strains using a modification of the previous methods [5]. Ten Staphylococcus aureus: (1R04) S. aureus, (1R06) S. aureus, (1R09) S. aureus, (2R04) S. aureus, (2RO5) S. aureus, (3R06) S. aureus, (3R09) S. aureus, (4R4) S. aureus, (4R5) S. aureus and (15Z1) S. aureus and five Enterococcus faecalis: (DEEL4-2) E. faecalis, (STL1-3) E. faecalis, (MP3-1) E. faecalis, (MP3-2) E. faecalis and (V2-2) E. faecalis. However, reference strains E. faecalis (ATCC 6569) and S. aureus (ATCC ${ }^{\circledR}$ 25923) were used for quality controls in this study. Holes (three) were bored in the plates (6 mm diameter) using sterile cork borer, about $20 \mu$ of the Schiff base complexes stock solution was inoculated across the wells and incubated at $37^{\circ} \mathrm{C}$ for $24 \mathrm{~h}$. Consequently, after incubation, the strains were classified as susceptible, or resistant and for the purposes of analysis, intermediate susceptibility was regarded as susceptible. The average diameter of three readings of the clear zone surrounding the hole was taken as the degree of inhibition against the bacteria and recorded as mean.

\section{Minimum inhibitory concentrations}

To evaluate the minimum inhibitory concentrations of the synthesized compounds. The following concentrations of 10.0 $\mu \mathrm{g} / \mathrm{ml}, 30.0 \mu \mathrm{g} / \mathrm{ml}, 60.0 \mu \mathrm{g} / \mathrm{ml}, 100.0 \mu \mathrm{g} / \mathrm{ml}, 247.2 \mu \mathrm{g} / \mathrm{ml}, 305.3$ $\mu \mathrm{g} / \mathrm{ml}, 378.9 \mu \mathrm{g} / \mathrm{ml}$ and $398.0 \mu \mathrm{g} / \mathrm{ml}$ were used. About $100 \mu \mathrm{l}$ aliquots of the bacterial suspensions were spread-plated on solidified Muller Hinton agar. Using sterile needles and paper discs that were previously autoclaved and soaked in different concentrations of the test samples were placed on the surface of the agar. The inoculated plates that contained the antibiotic (ampicillin and ciprofloxacin) and the test compounds were incubated aerobically at $37^{\circ} \mathrm{C}$ for $24 \mathrm{~h}$. After $24 \mathrm{~h}$ of incubation at $37^{\circ} \mathrm{C}$, the minimum inhibitory concentrations were documented.

\section{RESULTS AND DISCUSSION}

\section{Synthesis of the compounds}

The bidentate N-O Schiff bases viz: $N^{\prime}-\{(E)$-[4-(diethylamino)-2hydroxyphenyl] methylidene $\}-4-n i t r o b e n z o h y d r a z i d e ~\left(\mathrm{HL}^{1}\right)$ and $N^{\prime}$ $\{(E)$-[4-(diethylamino)-2-hydroxyphenyl] methylidene\}-4-methoxybenzohydrazide $\left(\mathrm{HL}^{2}\right)$ were synthesised by the condensation reaction of 4-(diethylamino)-2-hydroxybenzaldehyde and 4nitrobenzohydrazide/4-methoxybenzohydrazide (scheme 1). The Schiff base metal complexes were obtained by the reaction of metal acetylacetonates: $\mathrm{M}(\mathrm{acac})_{2}$ in methanol with the Schiff base ligand in a 1:1-mole ratio as shown in scheme 2 . 


\section{Fourier transform infrared spectroscopy (FT-IR)}

IR spectra gives some valuable information in coordination chemistry. In order to study the binding pattern of the Schiff base ( $\left.\mathrm{HL}^{1}-\mathrm{HL}^{2}\right)$ to the cobalt (Co), manganese (Mn), and magnesium (Mg) in the complexes, the IR spectrum of the Schiff base ligands was compared with the spectra of the complexes. The FT-IR results are presented in tables 1 and 2 alongside their individual vibrational peaks.

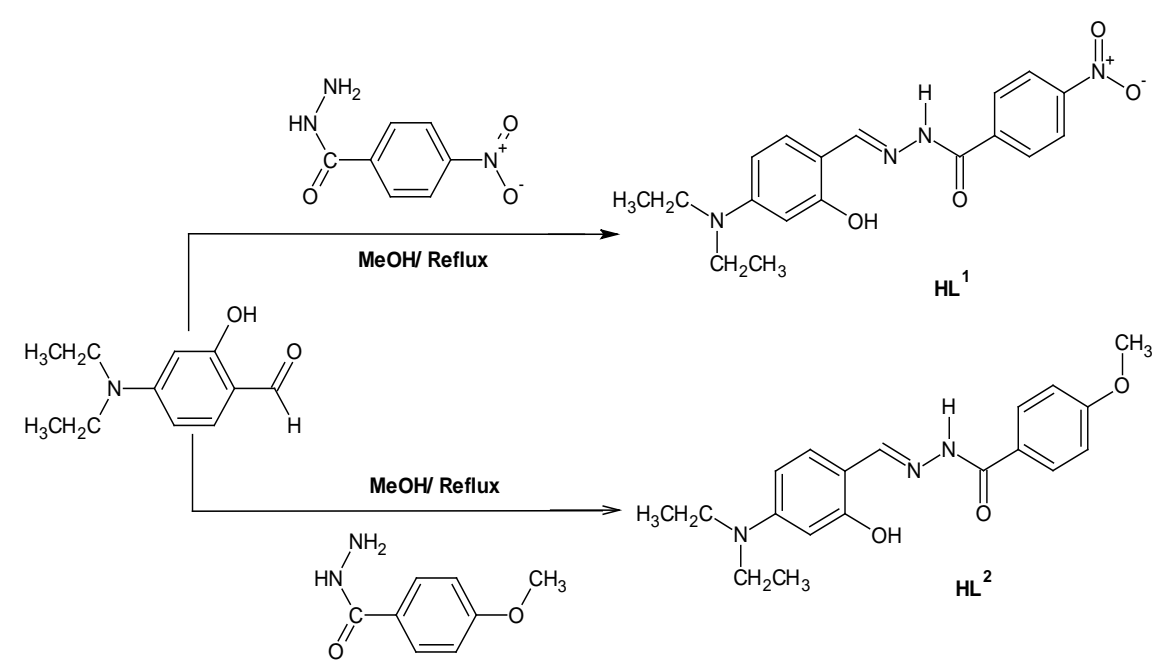

Scheme 1: Synthesis and structures of schiff base ligands (HL1-HL $\left.{ }^{2}\right)$<smiles>CCN(CC)c1ccc(/C=N/NC(=O)c2ccc([N+](=O)[O-])cc2)c(O)c1</smiles>

Where $\mathrm{M}=\mathrm{Mn}$ (II), $\mathrm{Co}$ (II), $\mathrm{Mg}$ (II)

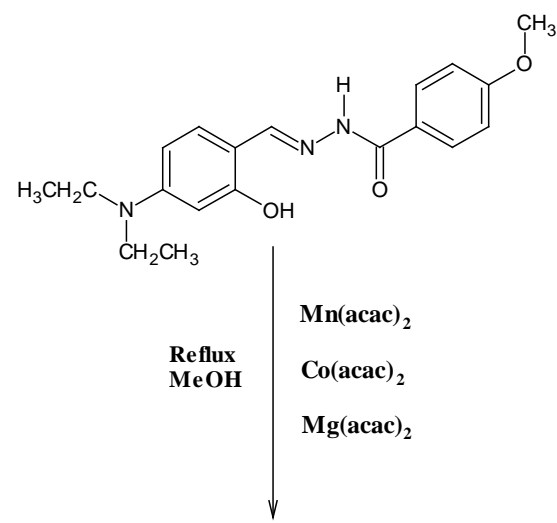

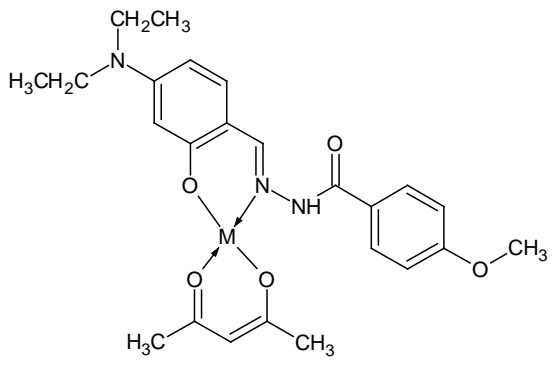

Where $\mathrm{M}=\mathrm{Mn}$ (II), Co(II), $\mathrm{Mg}$ (II)

Scheme 2: Detailed synthetic pathway for the schiff base complexes

IR spectra of the pure acetylacetone (acac) showed vibrational peaks at 2964 to $2877 \mathrm{~cm}^{-1}$ which are however similar to the observed stretching vibrational frequencies of $2868-2961 \mathrm{~cm}^{-1}$ (tables 1) in the spectrum of metal acetylacetonates [Co(acac) $2, \operatorname{Mn}($ acac) 2 , $\mathrm{Mg}$ (acac) 2] assignable to the methyl and methylene groups [15]. The vibrational frequency at $1704 \mathrm{~cm}^{-1}$, is due to carbonyl stretching vibration in the acetylacetone molecule.

This carbonyl frequency is absent or rather shifted downwards in the spectra of metal acetylacetonates indicating the formation of metal acetylacetonates bonds (M-O). This suggested that the coordination has taken place through oxygen atom of $\mathrm{C}=\mathrm{O}$ group.
The metal oxygen vibrational frequency, $v(M-0)$ was observed at different wavenumbers: $927 \mathrm{~cm}^{-1}, 921 \mathrm{~cm}^{-1}, 919 \mathrm{~cm}^{-1}$ for Co(acac) 2 , $\mathrm{Mn}(\mathrm{acac})_{2}, \mathrm{Mg}(\mathrm{acac})_{2}$ respectively [15-16].

The infrared spectra of the ligands $\left(\mathrm{HL}^{1}-\mathrm{HL}^{2}\right)$ showed that the vibrational frequency due to the phenolic $\mathrm{OH}$ group that appeared in the spectrum of the ligand at $3558 \mathrm{~cm}^{-1}$ and $3508 \mathrm{~cm}^{-1}$ for $\mathrm{HL}^{1}$ and $\mathrm{HL}^{2}$ had disappeared in the spectra of the complexes (table 2). This may be due to the displacement of its proton by the metal acetylacetonates $[9,13] . v(\mathrm{NH})$ of the uncoordinated $\mathrm{NH}$ groups appeared as a shoulder at $3274-3344 \mathrm{~cm}^{-1}$ in spectra of the ligands and at $3232-3358 \mathrm{~cm}^{-1}$ in spectra of the metal complexes [17]. The IR 
spectra of the free ligands show the characteristic $>\mathrm{C}=\mathrm{N}$ (azomethine group) bands in the $1623-1687 \mathrm{~cm}^{-1}$ region which are shifted to lower frequencies in the spectra of the metal complexes $\left(1608-1643 \mathrm{~cm}^{-1}\right)$ $[3,18]$. This $v(\mathrm{C}=\mathrm{N})$ shift to in all the complexes by about $15-44 \mathrm{~cm}^{-1}$ indicates the involvement of azomethine nitrogen in the coordination sphere with the metal ions for all the complexes as well as lack of carbonyl group from original substituted benzohydrazide compounds [17-18]. The stretching vibration of the phenolic $v(\mathrm{C}-0)$ observed at regions $1232-1237 \mathrm{~cm}^{-1}$ in the free ligands undergo a hypochromic shift to $1311-1340 \mathrm{~cm}^{-1}$ regions in the complexes upon complexation as recorded in table 2 . This shifts further confirms the coordination of the phenolic oxygen leading to the formation of C-O-M bond $[4,14,19]$ (where $\mathrm{M}=\mathrm{Co}, \mathrm{Mn}$ and $\mathrm{Mg}$ ).

Also, the appearance of new bands in the range of $839-850 \mathrm{~cm}^{-1}$ and $815-823 \mathrm{~cm}^{-1}$ suggests $v(\mathrm{M}-\mathrm{O})$ and $v(\mathrm{M}-\mathrm{N})$ frequencies, respectively $[4,17]$. The bands observed at $1576-1593 \mathrm{~cm}^{-1}$ is due to the $v(\mathrm{C}-\mathrm{C})$ stretching of the aromatic ring systems. In all the metal acetylacetonate-Schiff base complexes, most of the band shifts observed in the wave number region $1379-1436 \mathrm{~cm}^{-1}$ and 1240 $1259 \mathrm{~cm}^{-1}$ are in agreement with the structural changes observed in the molecular carbon skeleton after complexation, which cause some changes in $(\mathrm{C}-\mathrm{C})$ bond lengths. Valuable evidence concerning the environment of the functional group's coordination to the metal atoms through azomethine nitrogen and phenolic oxygen atoms has been obtained from the FT-IR spectra.

\section{Thermogravimetric analysis (TGA)}

Thermogravimetric and derivative thermogravimetric analysis (TGA/DTA) of the synthesized Schiff base compounds were measured under a nitrogen atmosphere at a heating rate of $5{ }^{\circ} \mathrm{C} \mathrm{min}$ ${ }^{1}$ from $0{ }^{\circ} \mathrm{C}$ to $900{ }^{\circ} \mathrm{C}$. TG/DTG results were plotted as percentage weight loss against temperature; provides insight into nature, properties of different molecules and the residues obtained after thermal decomposition.

Changes in the sample in the DTA curve show either exothermic or endothermic reaction taking place in the sample [10].

Table 1: Characteristic peaks of pure acetylacetone, $M$ (acac) 2 and Schiff base ligands

\begin{tabular}{|c|c|c|c|c|c|c|c|}
\hline \multicolumn{5}{|c|}{ Acetylacetone and M(acac) 2 peaks $\left(\mathrm{cm}^{-1}\right)$} & \multicolumn{3}{|c|}{ Schiff base ligands peaks $\left(\mathrm{cm}^{-1}\right)$} \\
\hline Assignment & $\mathrm{C}_{5} \mathrm{H}_{8} \mathrm{O}_{2}$ & Co(acac) 2 & Mn(acac) 2 & $\operatorname{Mg(acac)} 2$ & Assignment & $\mathrm{HL}^{1}$ & $\mathbf{H L}^{2}$ \\
\hline$v\left(\mathrm{CH}_{3}\right)$ & 2964 & 2950 & 2961 & 2954 & $v(\mathrm{O}-\mathrm{H})_{\mathrm{str}}$ & 3558 & 3508 \\
\hline$v\left(\mathrm{CH}_{3}\right)$ & 2917 & 2904 & & & $v(\mathrm{~N}-\mathrm{H})_{\mathrm{str}}$ & 3344 & 3288 \\
\hline$v\left(\mathrm{CH}_{3}\right)$ & 2877 & 2871 & 2868 & 2869 & & 3274 & \\
\hline$v(\mathrm{C}=0$ & 1704 & 1627 & 1604 & 1601 & $v(\mathrm{C}-\mathrm{H})_{\mathrm{str}}$ & 2973 & 2960 \\
\hline$v(\mathrm{CO})(\mathrm{acac})$ & 1600 & & & & & 2927 & \\
\hline$\delta\left(\mathrm{CH}_{3}\right)_{\text {asy }}$ & & 1515 & 1502 & 1520 & & & 2890 \\
\hline$\delta\left(\mathrm{CH}_{3}\right)_{\text {asy }}$ & 1411 & & & & $v(\mathrm{C}=\mathrm{N})_{\mathrm{str}}$ & 1623 & 1687 \\
\hline$\delta\left(\mathrm{CH}_{3}\right)_{\text {as }}$ & 1357 & 1349 & 1339 & 1379 & $v(\mathrm{C}=\mathrm{C})_{\mathrm{Ar}}$ & 1589 & 1589 \\
\hline$v(\mathrm{C}-\mathrm{C}-\mathrm{C})_{\mathrm{s}}$ & 1243 & 1272 & 1255 & 1259 & & & 1585 \\
\hline$v(\mathrm{M}-\mathrm{O})$ & & 927 & 921 & 919 & $v(\mathrm{C}-\mathrm{H})$ & 1515 & 1515 \\
\hline$v(\mathrm{C}-\mathrm{H})$ & 912 & 769 & 778 & 762 & & 1413 & \\
\hline \multirow[t]{9}{*}{$\delta$ (ring) } & 777 & 665 & & & $v(\mathrm{C}-\mathrm{C})$ & 1340 & 1341 \\
\hline & & & & & & 1240 & 1297 \\
\hline & & & & & $v(\mathrm{C}-\mathrm{O})_{\mathrm{str}}$ & 1237 & 1232 \\
\hline & & & & & $v(\mathrm{~N}-\mathrm{N})_{\mathrm{str}}$ & 1141 & 1140 \\
\hline & & & & & $v(\mathrm{C}-\mathrm{C})$ skeletal & 1130 & 1130 \\
\hline & & & & & & 1027 & 1054 \\
\hline & & & & & $v(\mathrm{C}-\mathrm{H})$ bending & 1012 & 1025 \\
\hline & & & & & Ring in plane & 848 & 835 \\
\hline & & & & & Ring out of plane & 701 & 703 \\
\hline
\end{tabular}

M(acac) 2-Metal acetylacetonate; Co-Cobalt; Mn-Manganese; Mg-Magnesium; HL1- $N^{\prime}-\{(E)$-[4-(diethylamino)-2-hydroxyphenyl]methylidene\}-4nitrobenzohydrazide; $\mathrm{HL}^{2}-N^{\prime}-\{(E)$-[4-(diethylamino)-2-hydroxyphenyl]methylidene $\}$-4-methoxybenzohydrazide; cm-centimetre.

Table 2: Characteristic IR bands $\left(\mathrm{cm}^{-1}\right)$ of the Schiff base metal complexes

\begin{tabular}{|c|c|c|c|c|c|c|}
\hline Assignment & Co(acac) $\left(L^{1}\right)$ & $\operatorname{Mn}(\operatorname{acac})\left(L^{1}\right)$ & $\operatorname{Mg}(\operatorname{acac})\left(L^{1}\right)$ & $\operatorname{Co}(\operatorname{acac})\left(L^{2}\right)$ & $\operatorname{Mn}(\operatorname{acac})\left(L^{2}\right)$ & $\operatorname{Mg}(\operatorname{acac})\left(L^{2}\right)$ \\
\hline$v(\mathrm{~N}-\mathrm{H})_{\mathrm{str}}$ & 3358 & 3290 & 3349 & 3232 & 3236 & 3357 \\
\hline \multirow[t]{2}{*}{$v(\mathrm{C}-\mathrm{H})_{\mathrm{str}}$} & 2927 & 2915 & 2971 & 2964 & 2973 & 2910 \\
\hline & 2892 & 2888 & 2865 & 2876 & 2832 & 2829 \\
\hline$v(\mathrm{C}=0)_{\mathrm{str}}$ & 1714 & 1705 & 1687 & 1699 & 1706 & 1681 \\
\hline$v(\mathrm{C}=\mathrm{N})_{\mathrm{str}}$ & 1617 & 1608 & 1613 & 1639 & 1643 & 1612 \\
\hline$v(\mathrm{C}=\mathrm{C})_{\mathrm{Ar}}$ & 1587 & 1577 & 1589 & 1576 & 1591 & 1593 \\
\hline$v(\mathrm{C}-\mathrm{O}-\mathrm{C})_{\mathrm{str}}$ & 1487 & 1498 & 1434 & 1463 & 1496 & 1481 \\
\hline$v(\mathrm{C}-\mathrm{C})$ skeletal & 1409 & 1403 & 1365 & 1436 & 1421 & 1379 \\
\hline$v(\mathrm{C}-\mathrm{O})_{\mathrm{str}}$ & 1340 & 1327 & 1336 & 1321 & 1317 & 1311 \\
\hline$v(\mathrm{C}-\mathrm{C})$ skeletal & 1240 & 1243 & 1240 & 1259 & 1255 & 1245 \\
\hline$v(\mathrm{~N}-\mathrm{N})_{\mathrm{str}}$ & 1137 & 1135 & 1128 & 1138 & 1133 & 1125 \\
\hline$v(\mathrm{C}-\mathrm{H})$ bending & 1014 & 1041 & 1010 & 1025 & 1018 & 1012 \\
\hline$v(\mathrm{M}-\mathrm{O})$ & 848 & 850 & 848 & 840 & 842 & 839 \\
\hline$v(\mathrm{M}-\mathrm{N})$ & 817 & 823 & 815 & 820 & 817 & 821 \\
\hline Ring in plane & 788 & 773 & 784 & 761 & 763 & 761 \\
\hline Ring out of plane & 701 & 703 & 700 & 665 & 667 & 619 \\
\hline
\end{tabular}

Co-Cobalt; Mn-Manganese; Mg-Magnesium; (acac)-acetylacetonate; L L $^{1}-N^{\prime}-\{(E)$-[4-(diethylamino)-2-hydroxyphenyl] methylidene $\}-4-$ nitrobenzohydrazide; $\mathrm{L}^{2}-N^{\prime}-\{(E)$-[4-(diethylamino)-2-hydroxyphenyl] methylidene $\}$-4-methoxybenzohydrazide; cm-centimetre. 
The TG-DTG curve of Schiff base $\left(\mathrm{HL}^{1}\right)$ is shown in fig. 1 . There are two main weight loss stages for the decomposition process. The peak at about $42.83{ }^{\circ} \mathrm{C}$ could be assigned as the vaporization of moisture while the peak at $253.83{ }^{\circ} \mathrm{C}$ indicates the melting of the ligand. The decomposition progressed to $315{ }^{\circ} \mathrm{C}$, with the temperature of the highest decomposition observed at about $287{ }^{\circ} \mathrm{C}$.
The thermogram of the Schiff base $\left(\mathrm{HL}^{2}\right)$, reveals a thermal stability of $280{ }^{\circ} \mathrm{C}$ with single-stage decomposition temperature with a reaction interval of $60{ }^{\circ} \mathrm{C}$. The compound was stable up to $260{ }^{\circ} \mathrm{C}$ and its decomposition started at $272^{\circ} \mathrm{C}$ and finally completed at 340 ${ }^{\circ} \mathrm{C}$, with the temperature of the highest decomposition observed at about $316^{\circ} \mathrm{C}$ (fig. 2) [4, 12].

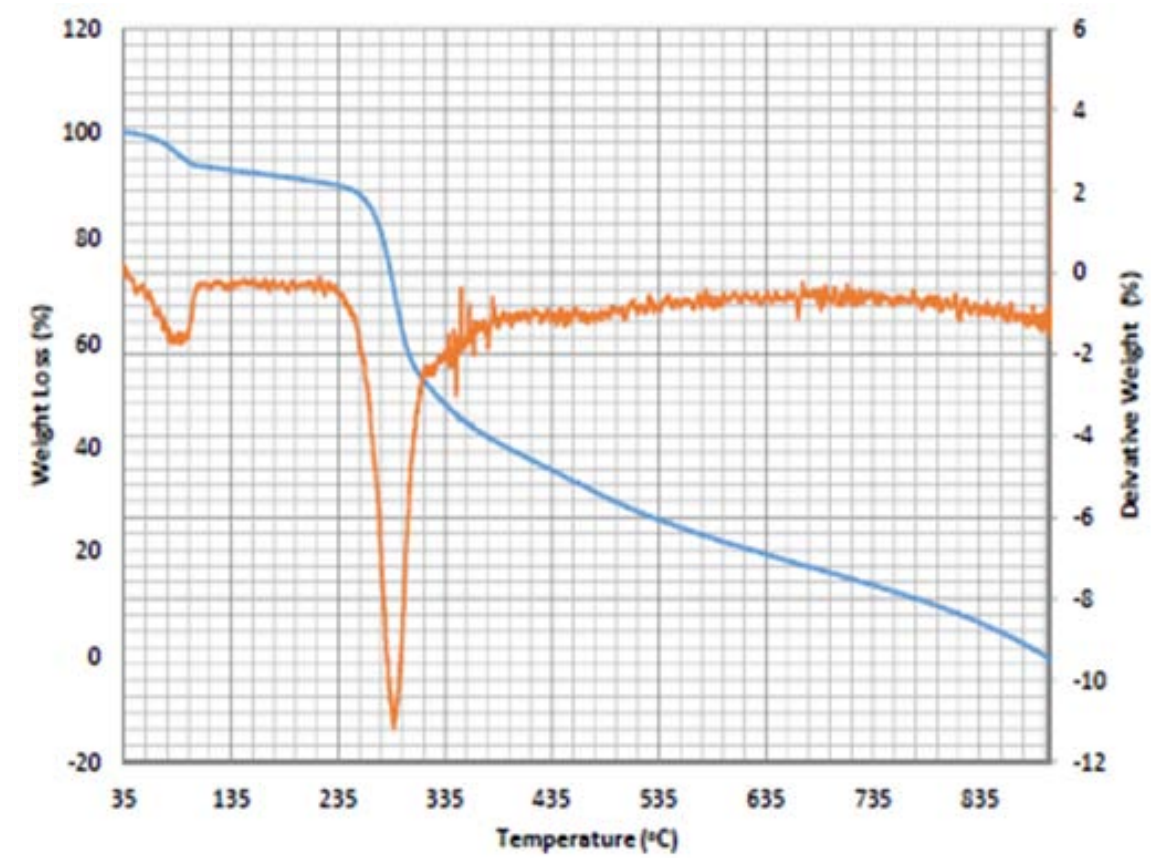

Fig. 1: TG/DTG curves for Schiff base, $H^{1}: N^{\prime}$-\{(E)-[4-(diethylamino)-2-hydroxyphenyl] methylidene\}-4-nitrobenzohydrazide

$\mathrm{Mn}$ (acac) $\left(\mathrm{L}^{1}\right)$ was stable up to $60^{\circ} \mathrm{C}$ and its decomposition started at $62{ }^{\circ} \mathrm{C}$ and finally completed at $425^{\circ} \mathrm{C}$. In the DTA thermogram of the $\mathrm{Mn}(\mathrm{acac})\left(\mathrm{L}^{1}\right)$ reveals four endothermal peaks caused by de-nitration $\left(\mathrm{NO}_{2}\right)$, diethylamino, acetylacetonate and Schiff ligand molecule, the remaining mass seems likely to correspond to $\mathrm{Mn}_{2} \mathrm{O}_{3}$ (fig. 3). $\mathrm{Mg}(\mathrm{acac})\left(\mathrm{L}^{2}\right)$ weight loss started at about $85{ }^{\circ} \mathrm{C}$ revealing four endothermal peaks corresponding to the removal of methoxylation, diethylamino, acetylacetonate and Schiff ligand molecule, the remaining mass seems likely to correspond to $\mathrm{MgO}$ as a residue (fig. 4) $[4,10]$. However, the number of decomposition processes (stages) gives an indication of the degree of purity synthesised Schiff base ligands and their corresponding metal complexes $[12,20]$.

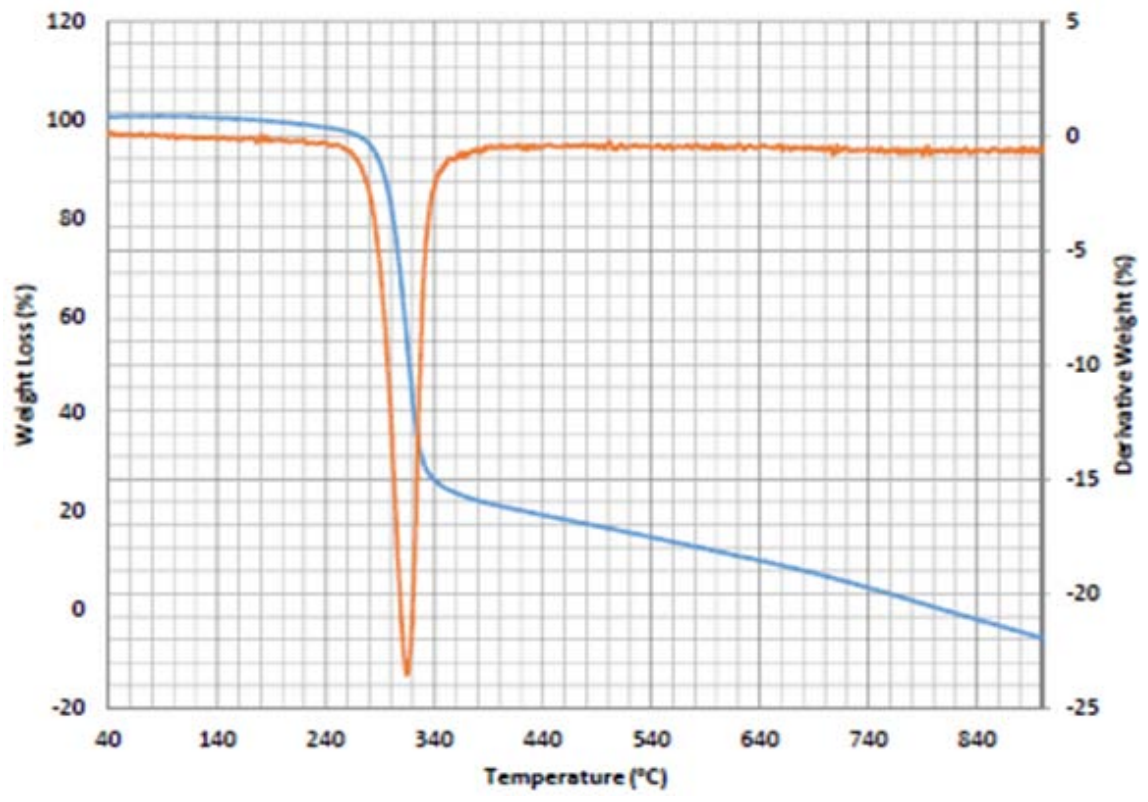

Fig. 2: TG/DTG curves for Schiff base, $\mathrm{HL}^{2}: N^{\prime}-\{(E)-[4-($ diethylamino)-2-hydroxyphenyl] methylidene\}-4-methoxybenzohydrazide 


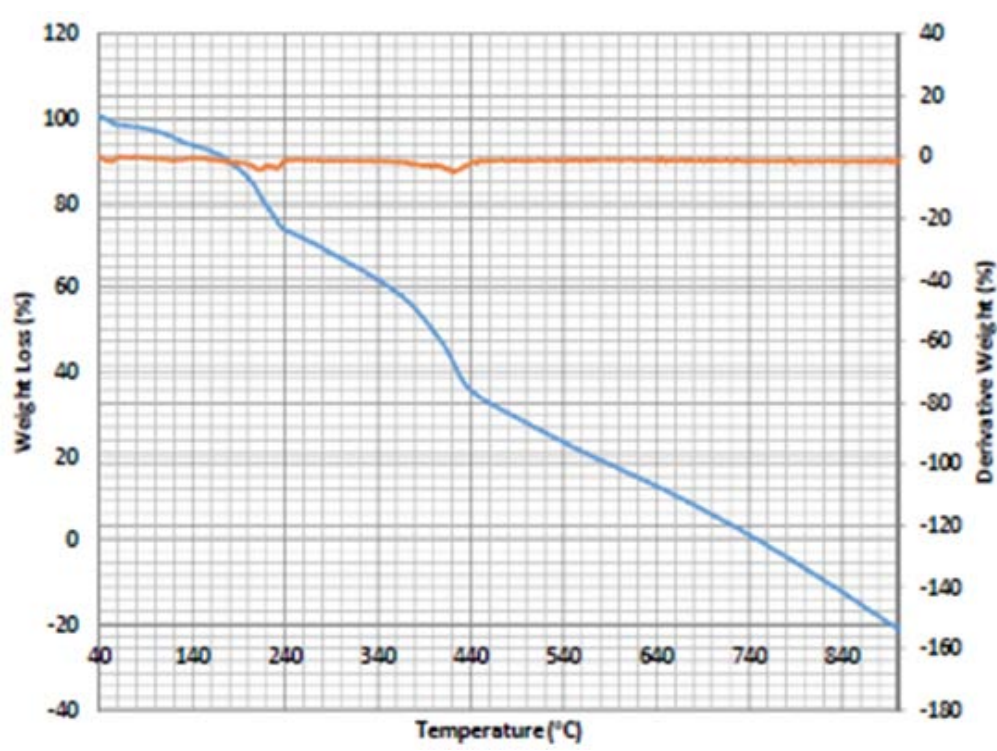

Fig. 3: TG/DTG curves for Mn(acac)(L1): Manganese acetylacetonato( $N^{\prime}-\{(E)$-[4-(diethylamino)-2-hydroxyphenyl]methylidene\}-4methoxybenzohydrazide)

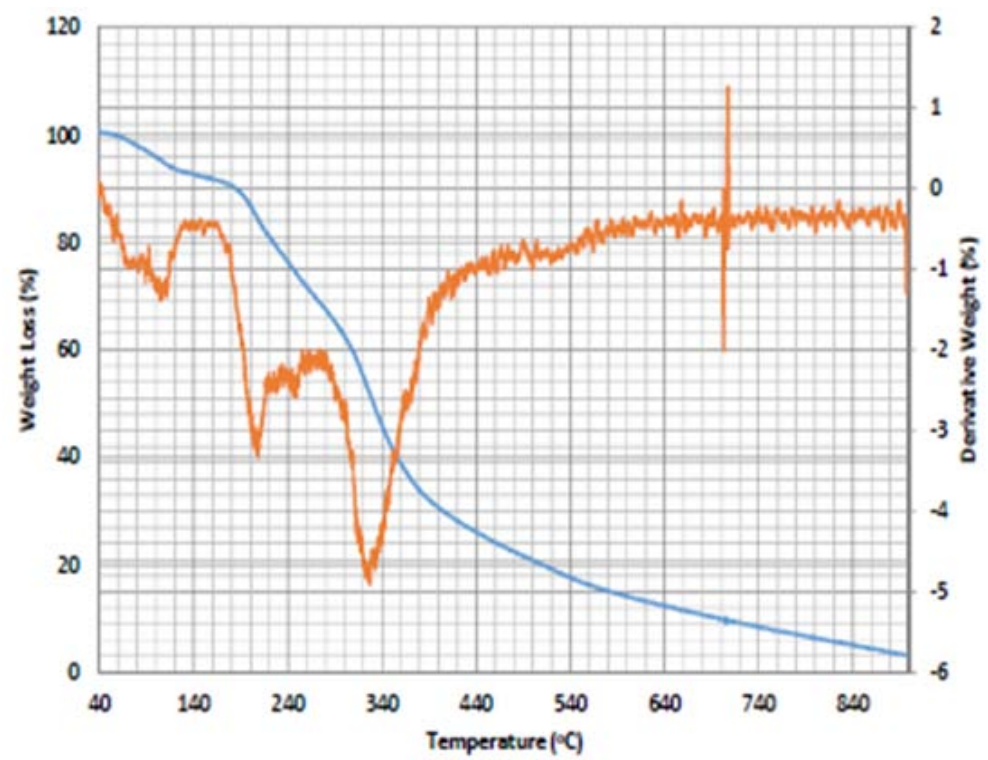

Fig. 4: TG/DTG curves for $\operatorname{Mg}(\operatorname{acac})\left(L^{2}\right)$ : Magnesium acetylacetonato $\left(N^{\prime}-\{(E)-[4-(\right.$ diethylamino $)-2$-hydroxyphenyl]methylidene $\}-4-$ methoxybenzohydrazide)

\section{${ }^{1} \mathrm{H}$ NMR and ${ }^{13} \mathrm{C}$ NMR spectral studies}

Proton and carbon-13 nuclear magnetic resonance spectroscopy of Schiff base ligands and their metal complexes were measured in $\mathrm{d}_{6}$ DMSO solution at room temperature with tetramethylsilane (TMS) as an internal standard.

${ }^{1} \mathrm{H}$ NMR spectrum of Schiff base $\left(\mathrm{HL}^{1}\right)$ reveals the presence of a phenolic proton at $\delta 12.07 \mathrm{ppm}(1 \mathrm{H}, \mathrm{s})$. While the signal due to the $\mathrm{NH}$ group appeared at $\delta 11.32 \mathrm{ppm}(1 \mathrm{H}, \mathrm{s})$, azomethine proton $(-\mathrm{HC}=\mathrm{N})$ at $\delta 8.46 \mathrm{ppm}(1 \mathrm{H}, \mathrm{s})$, aromatic protons at $\delta 8.38(1 \mathrm{H}, \mathrm{d}), \delta 8.36(1 \mathrm{H}, \mathrm{d}), \delta$ $8.16(1 \mathrm{H}, \mathrm{d}) \mathrm{ppm}$. Many signals appearing as multiplets in the $\delta 6.29$ $7.23 \mathrm{ppm}$ region are due to the aromatic protons, methylene protons at the range $\delta 3.34-3.39 \mathrm{ppm}$ (multiplets), methyl protons at $1.11(3 \mathrm{H}$, t) ppm (fig. 5). In the ${ }^{13} \mathrm{C}$ NMR spectrum, the signal of $161.0 \mathrm{ppm}$ is due to the phenolic carbon, amide carbon at $\delta 160.3 \mathrm{ppm}, \delta 151.3 \mathrm{ppm}$ $(\mathrm{C}=\mathrm{N})$ is due to carbon atom in the azomethine groups, aromatic carbons at $\delta 150.8,149.7,139.4,132.7,130.0,124.1,106.8,104.3 \mathrm{ppm}$, methylene carbon at $\delta 44.3 \mathrm{ppm}$, methyl carbon at $\delta 13.01$ ppm (fig. 6) $[4,14,17]$.

Similarly, ${ }^{1} \mathrm{H}$ NMR spectrum of Schiff base $\left(\mathrm{HL}^{2}\right)$ show some signals at $\delta 11.76 \mathrm{ppm}(1 \mathrm{H}, \mathrm{s})$ that is attributed to the phenolic proton. While the signal due to the $\mathrm{NH}$ group appeared at $\delta 11.27 \mathrm{ppm}(1 \mathrm{H}$, s), azomethine proton $(-\mathrm{HC}=\mathrm{N})$ at $\delta 8.43 \mathrm{ppm}(1 \mathrm{H}, \mathrm{s})$, aromatic protons at $\delta 7.50(1 \mathrm{H}, \mathrm{d}), \delta 7.42(1 \mathrm{H}, \mathrm{d}), \delta 7.20(1 \mathrm{H}, \mathrm{d}) \mathrm{ppm}$. Many signals appearing as multiplets in the $\delta 6.26-7.18 \mathrm{ppm}$ region are due to the aromatic protons, methoxy proton $3.84(3 \mathrm{H}, \mathrm{s}) \mathrm{ppm}$ methylene protons at the range $\delta 3.33-3.38$ ppm (multiplets), methyl protons at $1.11(3 \mathrm{H}, \mathrm{t}) \mathrm{ppm}$ (fig. 7$)$. In the ${ }^{13} \mathrm{C}$ NMR spectrum, the signal of $162.41 \mathrm{ppm}$ is due to the phenolic carbon, amide carbon at $\delta 160.2 \mathrm{ppm}, \delta 159.7 \mathrm{ppm}(\mathrm{C}=\mathrm{N})$ is due to carbon atom in the azomethine groups, aromatic carbons at $\delta 150.6,150.4,136.0,132.0$, $130.5,120.1,119.0,113.2,108.6,104.1 \mathrm{ppm}$, methoxy carbon at 97.4 ppm, methylene carbon appeared at 55.3 and $44.3 \mathrm{ppm}$, methyl carbon at $\delta 13.02$ ppm (fig. 8) [4, 14, 17]. 


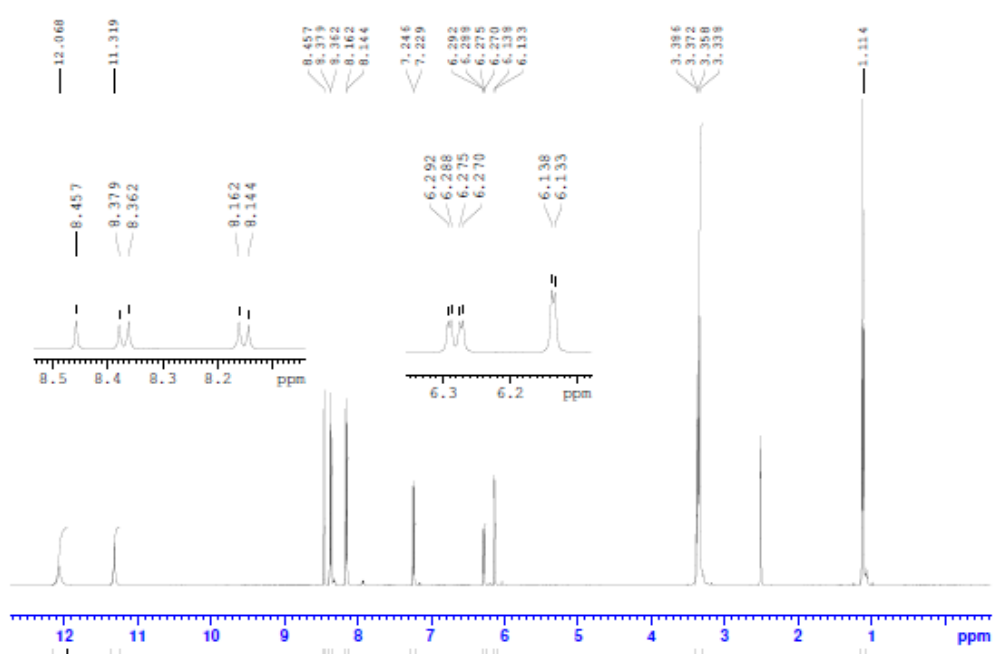

Fig. 5: Proton NMR for Schiff base, $H L^{1}: N^{\prime}-\{(E)$-[4-(diethylamino)-2-hydroxyphenyl] methylidene\}-4-nitrobenzohydrazide

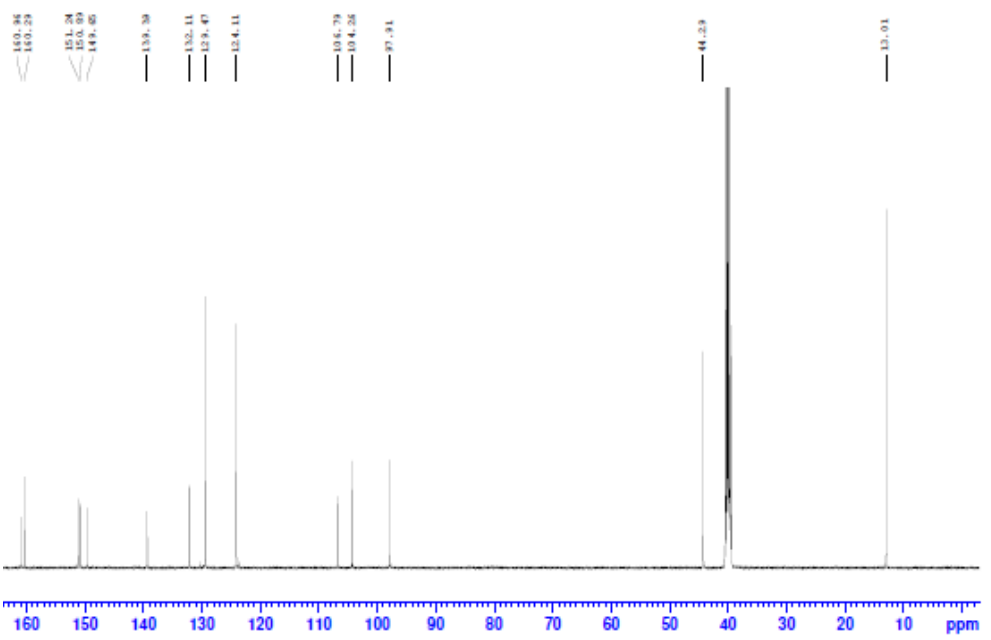

Fig. 6: Carbon-13 NMR for Schiff base, $\mathrm{HL}^{1}: N^{\prime}-\{(E)$-[4-(diethylamino)-2-hydroxyphenyl] methylidene\}-4-nitrobenzohydrazide

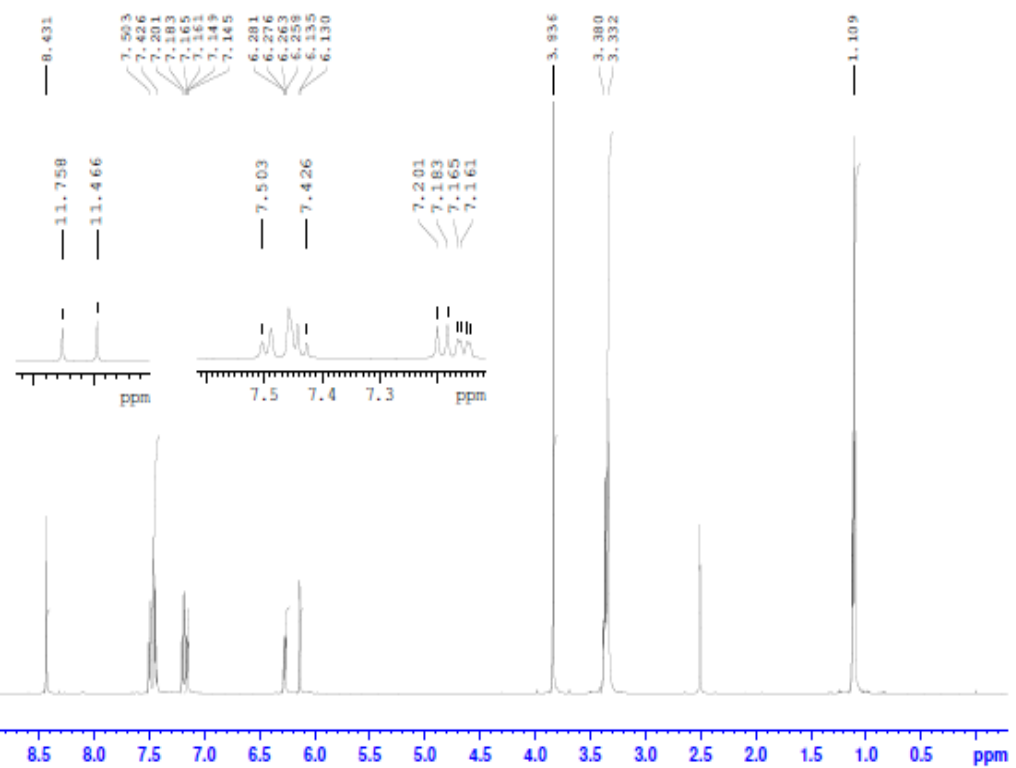

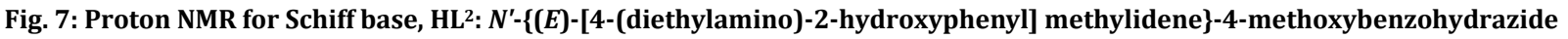




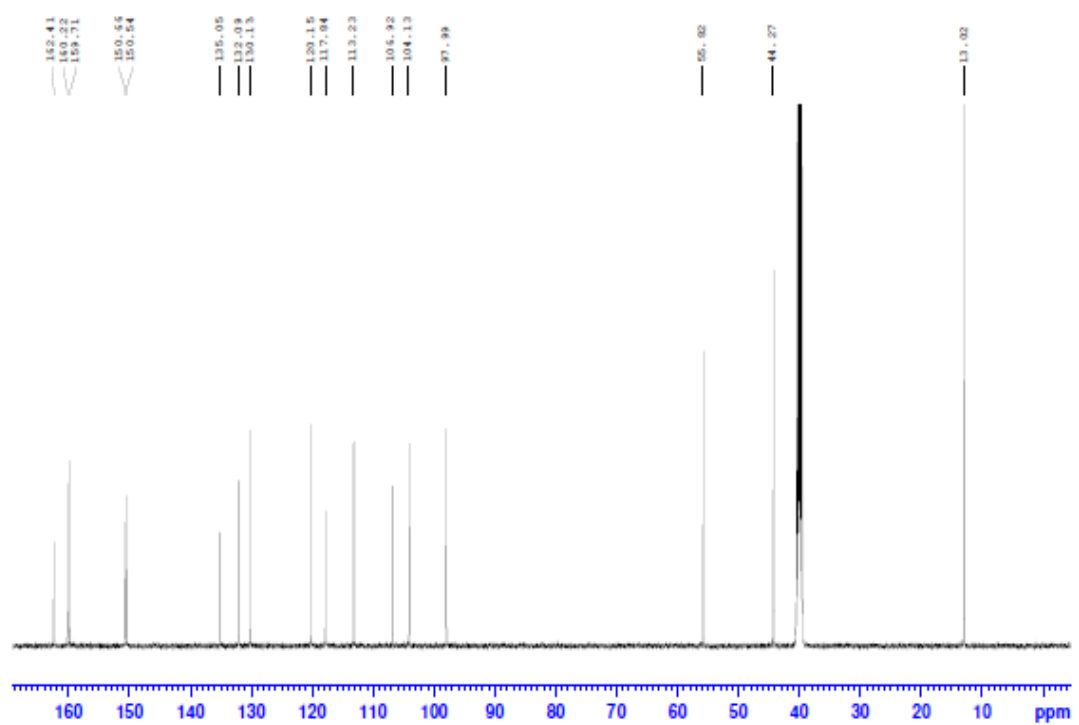

Fig. 8: Carbon-13 NMR for Schiff base, $\mathrm{HL}^{2}: N^{\prime}-\{(E)$-[4-(diethylamino)-2-hydroxyphenyl] methylidene\}-4-methoxybenzohydrazide

The spectrum of the complexes differs from that of the free ligands as explained. The disappearance of the signal due to the phenolic $\mathrm{OH}$ group is attributed to its involvement in coordination sphere with the corresponding metal ions $[12,17]$. The ${ }^{1} \mathrm{H}$ NMR spectrum of the complex: $\mathrm{Co}(\mathrm{acac})\left(\mathrm{L}^{1}\right)$ exhibited singlet signals at $\delta 12.06 \mathrm{ppm}$ which could be attributed to the proton of an amide nitrogen. The azomethine proton signal at $\delta 8.71 \mathrm{ppm}(1 \mathrm{H}, \mathrm{s})$, in the spectrum of the cobalt complex is shifted downfield compared to the free ligand, suggesting deshielding of the azomethine group due to the coordination with metal ions [21]. Aromatic protons at $\delta 8.45(1 \mathrm{H}$, $\mathrm{s}), \delta 8.99(1 \mathrm{H}, \mathrm{s}), \delta 8.37(1 \mathrm{H}, \mathrm{s}), \delta 8.16(1 \mathrm{H}, \mathrm{s})$, signals appearing as multiplets in the $\delta 6.14-7.26 \mathrm{ppm}$ region are due to the aromatic protons, methylene protons at the range $\delta$ 2.51-3.36 (multiplets), methyl protons at $\delta 2.04(3 \mathrm{H}, \mathrm{d}), \delta 1.11(3 \mathrm{H}, \mathrm{t}) \mathrm{ppm}$. The ${ }^{13} \mathrm{C}$ spectrum reveals the presence of ketonic carbon at $\delta 189.00 \mathrm{ppm}$, the signal of $\delta 167.3 \mathrm{ppm}$ is due to the phenolic carbon, amide carbon at $\delta 160.9 \mathrm{ppm}, \delta 160.2 \mathrm{ppm}(\mathrm{C}=\mathrm{N})$ is due to carbon atom in the azomethine groups, aromatic carbons at $\delta 150.9,149.6,139.4$, $132.1,129.5,124.1,104.3 \mathrm{ppm}$, methylene carbon at $\delta 44.3,26.0$ ppm, methyl carbon at $\delta 13.01 \mathrm{ppm}[4,14,17]$.

The ${ }^{1} \mathrm{H}$ NMR spectrum of the complex: $\operatorname{Mn}(\mathrm{acac})\left(\mathrm{L}^{1}\right)$ exhibited singlet signals at $\delta 11.83 \mathrm{ppm}$ which could be attributed to the proton of an amide nitrogen, azomethine proton signal at $\delta 8.38 \mathrm{ppm}$ $(1 \mathrm{H}, \mathrm{s})$, aromatic protons at $8.36(1 \mathrm{H}, \mathrm{s}), \delta 8.33(1 \mathrm{H}, \mathrm{s}), \delta 8.15(1 \mathrm{H}, \mathrm{s})$, $\delta 8.13(1 \mathrm{H}, \mathrm{s})$, signals appearing as multiplets in the $\delta 6.77-7.58 \mathrm{ppm}$ region are due to the aromatic protons, methylene protons at the range $\delta 2.51-3.33$ (multiplets), methyl protons at $\delta 2.06(3 \mathrm{H}, \mathrm{d}), \delta$ $1.22(3 \mathrm{H}, \mathrm{t}) \mathrm{ppm}$. The ${ }^{13} \mathrm{C}$ spectrum reveals the presence of ketonic carbon at $\delta 189.01 \mathrm{ppm}$, the signal of $\delta 161.4 \mathrm{ppm}$ is due to the phenolic carbon, amide carbon at $\delta 161.2 \mathrm{ppm}, \delta 152.2 \mathrm{ppm}(\mathrm{C}=\mathrm{N})$ is due to carbon atom in the azomethine groups, aromatic carbons at $\delta$ $150.3,149.6,140.0,131.1,129.5,129.1,123.3,121.7,112.3 \mathrm{ppm}$, methylene carbon at $\delta 26.0 \mathrm{ppm}$, methyl carbon at $\delta 13.2 \mathrm{ppm}[4,14$, $17,21]$.

The ${ }^{1} \mathrm{H}$ NMR spectrum of the complex: $\mathrm{Mg}(\mathrm{acac})\left(\mathrm{L}^{1}\right)$ exhibited singlet signals at $\delta 11.36 \mathrm{ppm}$ which could be attributed to the proton of an amide nitrogen, azomethine proton signal at $\delta 8.44 \mathrm{ppm}(1 \mathrm{H}, \mathrm{s})$, aromatic protons at $8.36(1 \mathrm{H}, \mathrm{s}), \delta 8.35(1 \mathrm{H}, \mathrm{s}), \delta 8.17(1 \mathrm{H}, \mathrm{s}), \delta 8.15$ $(1 \mathrm{H}, \mathrm{s})$, signals appearing as multiplets in the $\delta 6.13-7.23 \mathrm{ppm}$ region are due to the aromatic protons, methylene protons at the range $\delta$ 2.51-3.35 (multiplets), methyl protons at $\delta 2.14(3 \mathrm{H}, \mathrm{d}), \delta 1.72(3 \mathrm{H}$, $\mathrm{t}), \delta 1.11(3 \mathrm{H}, \mathrm{t}) \mathrm{ppm}$. The ${ }^{13} \mathrm{C}$ spectrum reveals the presence of ketonic carbon at $\delta 188.7 \mathrm{ppm}$, the signal of $\delta 161.0 \mathrm{ppm}$ is due to the phenolic carbon, amide carbon at $\delta 160.3 \mathrm{ppm}, \delta 151.3 \mathrm{ppm}$ $(\mathrm{C}=\mathrm{N})$ is due to carbon atom in the azomethine groups, aromatic carbons at $\delta 150.9,149.6,139.4,132.1,129.5,124.1,106.8,104.2$ ppm, methylene carbon at $\delta 44.3,28.15 \mathrm{ppm}$, methyl carbon at $\delta$ $13.01 \mathrm{ppm}[4,14,17,21]$.

The ${ }^{1} \mathrm{H}$ NMR spectrum of the complex: $\mathrm{Co}(\mathrm{acac})\left(\mathrm{L}^{2}\right)$ exhibited singlet signals at $\delta 11.41 \mathrm{ppm}$ which could be attributed to the proton of an amide nitrogen, azomethine proton signal at $\delta 8.30 \mathrm{ppm}(1 \mathrm{H}, \mathrm{s})$, aromatic protons at $7.89(1 \mathrm{H}, \mathrm{s}), \delta 7.88(1 \mathrm{H}, \mathrm{s}), \delta 7.54(1 \mathrm{H}, \mathrm{s}), \delta 7.52$ $(1 \mathrm{H}, \mathrm{s})$, signals appearing as multiplets in the $\delta 6.75-7.05 \mathrm{ppm}$ region are due to the aromatic protons, methoxy proton $3.83(3 \mathrm{H}, \mathrm{s}) \mathrm{ppm}$, methylene protons at the range $\delta$ 2.51-3.32 (multiplets), methyl protons at $\delta 2.05(3 \mathrm{H}, \mathrm{d}), \delta 1.02(3 \mathrm{H}, \mathrm{t}) \mathrm{ppm}$ (fig. 9). The ${ }^{13} \mathrm{C}$ spectrum reveals the presence of ketonic carbon at $\delta 189.01 \mathrm{ppm}$, the signal of $\delta 162.6 \mathrm{ppm}$ is due to the phenolic carbon, amide carbon at $\delta 162.2 \mathrm{ppm}, \delta 151.9 \mathrm{ppm}(\mathrm{C}=\mathrm{N})$ is due to carbon atom in the azomethine groups, aromatic carbons at $\delta 148.5,129.8,128.8$, $126.3,122.3,112.3 \mathrm{ppm}$, methoxy carbon at $97.3 \mathrm{ppm}$, methylene carbon at $\delta 55.9$ and $26.0 \mathrm{ppm}$, methyl carbon at $\delta 13.3 \mathrm{ppm}$ (fig. 10) $[4,14,17,21]$.

The ${ }^{1} \mathrm{H}$ NMR spectrum of the complex: $\mathrm{Mn}(\mathrm{acac})\left(\mathrm{L}^{2}\right)$ exhibited singlet signals at $\delta 11.43 \mathrm{ppm}$ which could be attributed to the proton of an amide nitrogen, azomethine proton signal at $\delta 7.86 \mathrm{ppm}$ $(1 \mathrm{H}, \mathrm{s})$, aromatic protons at $7.73(1 \mathrm{H}, \mathrm{s}), \delta 7.48(1 \mathrm{H}, \mathrm{s}), \delta 7.26(1 \mathrm{H}, \mathrm{s})$, $\delta 7.17(1 \mathrm{H}, \mathrm{s})$, signals appearing as multiplets in the $\delta 6.05-7.00 \mathrm{ppm}$ region are due to the aromatic protons, methoxy proton $3.79(3 \mathrm{H}, \mathrm{s})$ $\mathrm{ppm}$, methylene protons at the range $\delta$ 2.51-3.18 (multiplets), methyl protons at $\delta 2.09(3 \mathrm{H}, \mathrm{d}), \delta 1.10(3 \mathrm{H}, \mathrm{t}) \mathrm{ppm}$. The ${ }^{13} \mathrm{C}$ spectrum reveals the presence of ketonic carbon at $\delta 188.4 \mathrm{ppm}$, the signal of $\delta 162.2 \mathrm{ppm}$ is due to the phenolic carbon, amide carbon at $\delta 161.4 \mathrm{ppm}, \delta 151.9 \mathrm{ppm}(\mathrm{C}=\mathrm{N})$ is due to carbon atom in the azomethine groups, aromatic carbons at $\delta 145.5,130.0,128.9,124.3$, $114.1,112.3 \mathrm{ppm}$, methoxy carbon at $95.1 \mathrm{ppm}$, methylene carbon at $\delta 55.9$ and $25.8 \mathrm{ppm}$, methyl carbon at $\delta 13.14 \mathrm{ppm}[4,14,17,21]$.

The ${ }^{1} \mathrm{H}$ NMR spectrum of the complex: $\operatorname{Mg}(\mathrm{acac})\left(\mathrm{L}^{2}\right)$ exhibited singlet signals at $\delta 11.41 \mathrm{ppm}$ which could be attributed to the proton of an amide nitrogen, azomethine proton signal at $\delta 8.30 \mathrm{ppm}(1 \mathrm{H}, \mathrm{s})$, aromatic protons at $7.90(1 \mathrm{H}, \mathrm{s}), \delta 7.88(1 \mathrm{H}, \mathrm{s}), \delta 7.54(1 \mathrm{H}, \mathrm{s}), \delta 7.52$ $(1 \mathrm{H}, \mathrm{s})$, signals appearing as multiplets in the $\delta 6.75-7.05 \mathrm{ppm}$ region are due to the aromatic protons, methoxy proton $3.83(3 \mathrm{H}, \mathrm{s}) \mathrm{ppm}$, methylene protons at the range $\delta 2.50-3.33$ (multiplets), methyl protons at $\delta 1.71(3 \mathrm{H}, \mathrm{d}), \delta 1.22(3 \mathrm{H}, \mathrm{t}) \mathrm{ppm}$. The ${ }^{13} \mathrm{C}$ spectrum shows the presence of ketonic carbon at $\delta 188.67 \mathrm{ppm}$, the signal of $\delta 162.58 \mathrm{ppm}$ is due to the phenolic carbon, amide carbon at $\delta$ $162.26 \mathrm{ppm}, \delta 151.92 \mathrm{ppm}(\mathrm{C}=\mathrm{N})$ is due to carbon atom in the azomethine groups, aromatic carbons at $\delta 148.54,129.82,128.8$, $126.33,122.26,112.30 \mathrm{ppm}$, methoxy carbon at $99.0 \mathrm{ppm}$, methylene carbon at $\delta 55.87$ and $28.17 \mathrm{ppm}$, methyl carbon at $\delta 15.7$ $\operatorname{ppm}[4,14,17,21]$. 


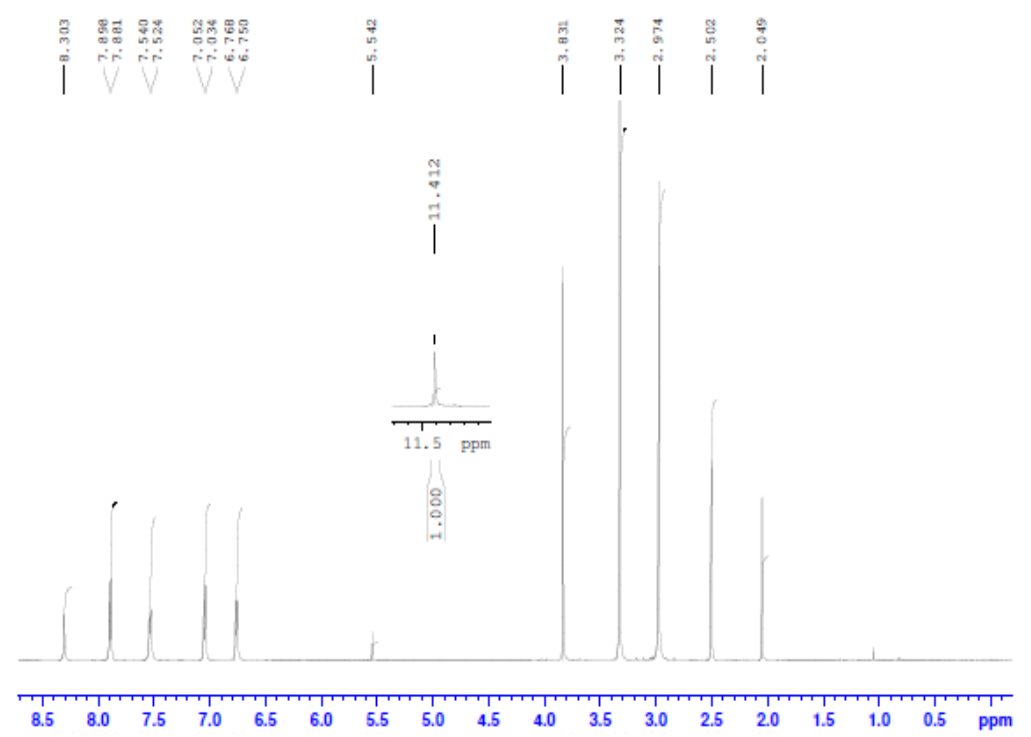

Fig. 9: Proton NMR for Co(acac) $\left(\mathrm{L}^{2}\right)$ : cobalt acetylacetonato $\left(N^{\prime}-\{(E)-[4-(\right.$ diethylamino $)-2$-hydroxyphenyl]methylidene $\}-4-$ methoxybenzohydrazide)

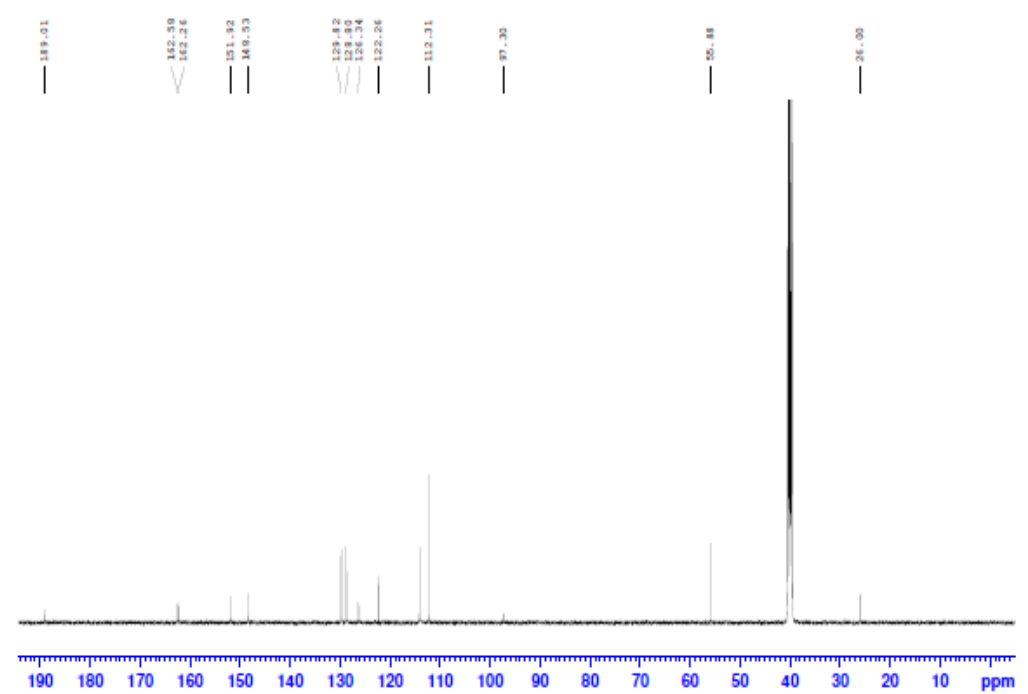

Fig. 10: Carbon-13 NMR for $\operatorname{Co}(\operatorname{acac})\left(\mathrm{L}^{2}\right)$ : cobalt acetylacetonato( $N^{\prime}-\{(E)-[4-($ diethylamino)-2-hydroxyphenyl]methylidene\}-4methoxybenzohydrazide)

\section{Biological evaluation}

The as-synthesized compounds were evaluated for in vitro antimicrobial activity. The activity was tested against two Grampositive bacteria, including Staphylococcus aureus and Enterococcus faecalis, using established antimicrobial agents as standards. The well-diffusion and disc diffusion methods were employed in screening the Schiff base ligands and their complexes for their sensitivity and minimum inhibitory concentration (MIC) respectively. Standard antibacterial compounds: ciprofloxacin and ampicillin were used as positive control. Many of the complexes and the ligands had no antimicrobial effects on both the environmental and control bacterial strains. The results of the biological studies are displayed in fig. 11 and 12.

The complexes showed more antibacterial activity than the free ligands. The screening data (zone of Inhibition) indicated that $\mathrm{Mn}(\mathrm{acac})\left(\mathrm{L}^{2}\right)$, with a 4-diethylamino and 4-methoxy group on the benzaldehyde and benzohydrazide rings respectively, showed the best antibacterial activity against $E$. faecalis and $S$. aureus among the synthesised Schiff base complexes (fig. 11 and 12). The compound: $\mathrm{Mn}(\mathrm{acac})\left(\mathrm{L}^{2}\right)$ effectiveness distinction is dependent either on the cell microbes' permeability or differences in the cells ribosomes [14]. The compound activity against all the species of the studied bacterial strains can be explained by Overtone's concept and Tweedy's chelation theory [4, 14]. With respect to Overtone's concept of cell permeability, the lipid materials surrounding the cell allow the passage of only the lipidsoluble materials leading to liposolubility and permeability through the lipid layer of cell membranes as a significant feature of antimicrobial activity $[9,13,22]$. Tweedy chelation theory $[9,12]$ supports the reduction of metal ion polarity to a considerable extent due to the overlap of the ligand orbital and partial sharing of the positive charge of the metal ion with donor groups. Chelation increases the delocalization of $\pi$-electrons within the chelate ring and enhances the lipophilicity of the complexes. This amplified lipophilicity enhances the penetration of the complex into lipid membranes, thereby, blocking of the metal binding sites in the enzymes of microorganisms. The compound also disturbs the respiratory process of the cell, thereby, hindering the synthesis of proteins, and restricts further organism growth $[4,9,13]$. 


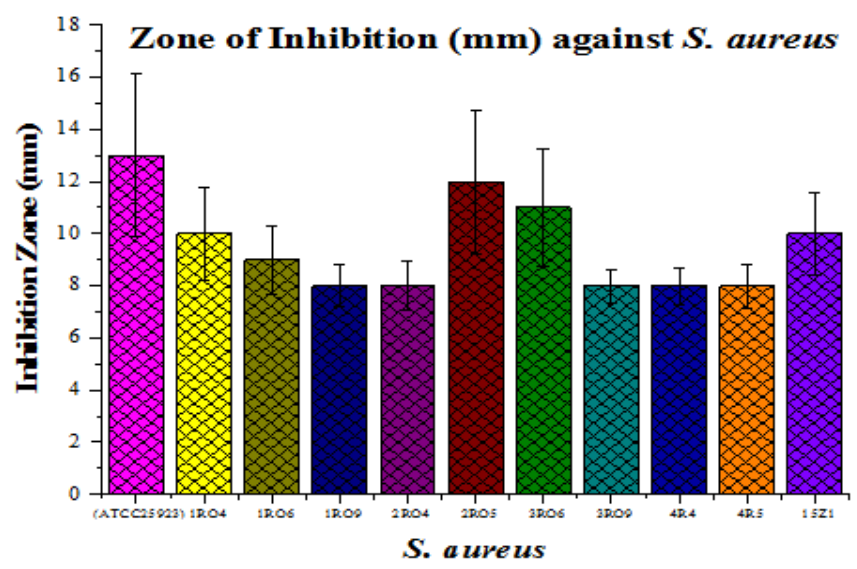

Fig. 11: Zone of Inhibition of manganese complex against Staphylococcus aureus, $\operatorname{Mn}(\operatorname{acac})\left(L^{2}\right)-M a n g a n e s e$ acetylacetonato( $N^{\prime}-\{(E)-[4-$ (diethylamino)-2-hydroxyphenyl]methylidene\}-4-methoxybenzohydrazide); mm-millimetre; S. aureus-Staphylococcus aureus; (ATCC 25923)-S. aureus; (1R04)-S. aureus; (1RO6)-S. aureus; (1R09)-S. aureus; (2R04)-S. aureus; (2RO5)-S. aureus; (3RO6)-S. aureus; (3R09)-S. aureus; (4R4)-S. aureus; (4R5)-S. aureus and (15Z1)-S. aureus, $\mathrm{n}=3, \mathrm{X} \pm \mathrm{SEM}$

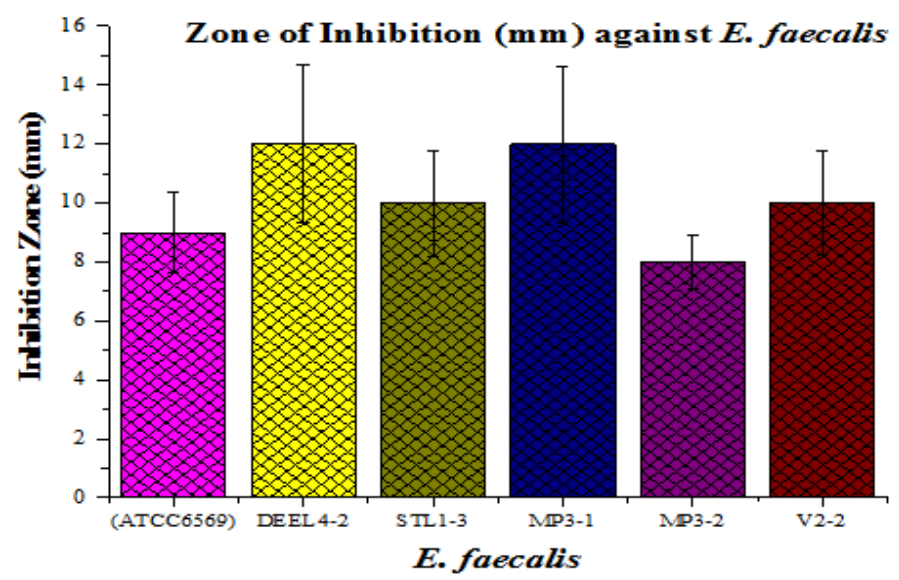

Fig. 12: Zone of Inhibition of manganese complex against Enterococcus faecalis, Mn(acac)( $\left.\mathrm{L}^{2}\right)$-Manganese acetylacetonato $\left(N^{\prime}-\{(E)-[4-\right.$ (diethylamino)-2-hydroxyphenyl]methylidene\}-4-methoxybenzohydrazide); mm-millimetre; E. faecalis-Enterococcus faecalis; (ATCC 6569)-E. faecalis; (DEEL4-2)-E. faecalis; (STL1-3)-E. faecalis; (MP3-1)-E. faecalis; (MP3-2)-E. faecalis and (V2-2)-E. faecalis, $\mathrm{n}=3, \mathrm{X} \pm \mathrm{SEM}$

In addition, the antibacterial activities of the discussed compounds depends on the kind of substituent on the benzo hydrazide rings at the para position. The compound with electron donating (methoxy) group on the benzo hydrazide rings at the para position showed the higher activity than the one with electron withdrawing (nitro) [23]. Schiff base complex $\mathrm{Mn}(\mathrm{acac})\left(\mathrm{L}^{2}\right)$ exhibited antimicrobial activities against both E. faecalis and S. aureus bacteria tested with a MIC of $398.0 \mu \mathrm{g} / \mathrm{ml}$ (table 4). However, $\operatorname{Mn}(\mathrm{acac})\left(\mathrm{L}^{2}\right)$ show lower antibacterial activity when compared to ciprofloxacin and ampicillin as standard drugs but their activities on preventing the growth of $E$. faecalis and $S$. aureus bacteria is satisfactory making them potential anti-Staphylococcus and anti-Enterococcus lead compounds.

Table 4: Antibacterial activity of manganese complex and standard agents

\begin{tabular}{|c|c|c|c|c|c|c|c|}
\hline \multirow[t]{2}{*}{ S. aureus } & $\mathrm{MnL}^{2}$ & Amp.* & Cipro.* & E. faecalis & $\mathrm{MnL}^{2}$ & Amp.* & Cipro.* \\
\hline & \multicolumn{3}{|c|}{ (MIC, $\mu \mathrm{g} / \mathrm{ml})$} & & \multicolumn{3}{|c|}{ (MIC, $\mu \mathrm{g} / \mathrm{ml})$} \\
\hline (ATCC25923) & 398.0 & 247.2 & 247.2 & (ATCC6569) & 398.0 & 247.2 & 305.3 \\
\hline $1 \mathrm{RO} 4$ & 398.0 & 247.2 & 247.2 & DEEL4-2 & 398.0 & 247.2 & 305.3 \\
\hline 1R06 & 398.0 & 247.2 & 247.2 & STL1-3 & 398.0 & 247.2 & 305.3 \\
\hline 1R09 & 398.0 & 247.2 & 247.2 & MP3-1 & 398.0 & 247.2 & 305.3 \\
\hline 2R04 & 398.0 & 247.2 & 247.2 & MP3-2 & 398.0 & 247.2 & 305.3 \\
\hline 2R05 & 398.0 & 247.2 & 247.2 & V2-2 & 398.0 & 247.2 & 305.3 \\
\hline $3 \mathrm{R} 06$ & 398.0 & 247.2 & 247.2 & & & & \\
\hline 3R09 & 398.0 & 247.2 & 247.2 & & & & \\
\hline $4 \mathrm{R} 4$ & 398.0 & 247.2 & 247.2 & & & & \\
\hline $4 \mathrm{R} 5$ & 398.0 & 247.2 & 247.2 & & & & \\
\hline $15 Z 1$ & 398.0 & 247.2 & 247.2 & & & & \\
\hline
\end{tabular}

Mn-Manganese; L L2-N'-\{(E)-[4-(diethylamino)-2-hydroxyphenyl]methylidene\}-4-methoxybenzohydrazide; S. aureus-Staphylococcus aureus; (ATCC 25923)-S. aureus; (1R04)-S. aureus, (1R06)-S. aureus, (1RO9)-S. aureus, (2R04)-S. aureus, (2RO5)-S. aureus, (3R06)-S. aureus; (3R09)-S. aureus; (4R4)-S. aureus; (4R5)-S. aureus; (15Z1)-S. aureus; E. faecalis-Enterococcus faecalis; (ATCC 6569)-E. faecalis; (DEEL4-2)-E. faecalis; (STL1-3)-E. faecalis; (MP3-1)-E. faecalis; (MP3-2)-E. faecalis; (V2-2)-E. faecalis; Amp.-ampicillin; Cipro--ciprofloxacin; *-Standards; MIC-Minimum Inhibitory Concentrations; $\mu \mathrm{g} / \mathrm{ml}$-microgram/millimetre. 


\section{CONCLUSION}

The Schiff bases $\left(\mathrm{HL}^{1}-\mathrm{HL}^{2}\right)$, derived from the condensation reaction of 4-(diethylamino)-2-hydroxybenzaldehyde and 4-nitrobenzohydrazide/or 4-methoxybenzohydrazide. The Schiff base metal complexes synthesized via metal acetylacetonates with the Schiff base ligands reaction were characterized. From the spectra, it can be concluded that the ligands acted as bidentate moieties, binding to the metal ions: cobalt, manganese, and magnesium in the complexes through azomethine $\mathrm{N}$ and phenolic 0 . The biological activity revealed that $\mathrm{Mn}(\mathrm{acac})\left(\mathrm{L}^{2}\right)$ complex exhibited good inhibition against all the E. faecalis and $S$. aureus strains used, but lower antibacterial activity when compared to the ciprofloxacin and ampicillin (standard antibiotic) used in this study. In addition, the antibacterial activity of the compound depends on the kind of substituent on the benzo hydrazide rings at the para position. The compound bearing the Schiff base with electron donating (methoxy) group on the benzo hydrazide rings at the para position showed the higher activity than the Schiff base with electron withdrawing (nitro). The obtained results suggest the compound as promising chemotherapeutic agents for further structural optimization.

\section{ACKNOWLEDGEMENT}

The authors gratefully acknowledge the financial support of Directorate of Research, Vaal University of Technology, Vanderbijlpark, South Africa.

\section{AUTHORS' CONTRIBUTION}

Charity W. Dikio carried out the experiment and analysis. Ikechukwu P. Ejidike researched and wrote the article. Fanyana M. Mtunzi supervised the project and revision. Michael J. Klink provided support towards the project. Ezekiel D. Dikio provided the necessary guidance and critical review.

\section{CONFLICTS OF INTERESTS}

The authors declare that they have no conflict of interest.

\section{REFERENCES}

1. Iqbal J, Siddiqui R, Kazmi SU, Khan NA. A simple assay to screen antimicrobial compounds potentiating the activity of current antibiotics. Biomed Res Int 2013. http://dx.doi.org/ $10.1155 / 2013 / 927323$

2. Ejidike IP, Ajibade PA. Transition metal complexes of symmetrical and asymmetrical schiff bases as antibacterial, antifungal, antioxidant, and anticancer agents: progress and prospects. Rev Inorg Chem 2015;35:191-224.

3. Kajal A, Bala S, Kamboj S, Sharma N, Saini V. Schiff bases: a versatile pharmacophore. J Catal 2013. http://dx.doi.org/ 10.1155/2013/893512

4. Parsaee Z, Mohammadi K. Synthesis, characterization, nanosized binuclear nickel complexes, DFT calculations and antibacterial evaluation of new macrocyclic schiff base compounds. J Mol Struct 2017;1137:512-23.

5. Bartyzel A. Synthesis, crystal structure and characterization of Manganses(III) complex containing a tetradentate schiff base. J Coord Chem 2013;66:4292-303.

6. Upadhayay N. Synthesis, characterization and biological studies of some Thiocyanato-bridged bimetallic complexes containing $\mathrm{Co}(\mathrm{II}), \mathrm{Cd}(\mathrm{II}), \mathrm{Hg}(\mathrm{II})$ and $N, N$ Bis(benzylidene)-1,2-phenylenediamine schiff base. Chem Sci Trans 2013;2:455-60.

7. Bruckner C, Rettig SJ, Dolphin D. 2-PyrrolyLthiones as monoanionic bidentate N,S-chelators: Synthesis and molecular structure of 2-pyrrolthionnato complexes of Nickel(II), Cobalt(III), Mercury(II). Inorg Chem 2000;39:6100-6.
8. Muruganandam L, Kumar KK, Balasubramanian K. Synthesis, characterization, antibacterial, antifungal and anticancer studies of a new antimetabolite: $N$-[(Diphenylamino) methyl]acetamide and some of its inner transition metal chelates. Chem Sci Trans 2013;2:379-84.

9. Madhavi K, Sree Ramya G. Synthesis, antioxidant and antiinflammatory activities of ethyl 2-(2-cyano-3-(substituted phenyl)acrylamido)-4,5-dimethylthiophene-3-carboxylates. Asian J Pharm Clin Res 2017;10:95-100.

10. Sahebalzamani S, Ghammamy S, Mehrani K, Salimi F. Synthesis, characterization and thermal analysis of $\mathrm{Hg}(\mathrm{II})$ complexes with hydrazide ligands. Chem Sin 2010;1:67-72.

11. Benabid S, Douadi T, Debab H, De Backer M, Sauvage F. Synthesis, spectroscopic, and electrochemical characterization of a schiff base: 4,4-bis[(4-diethylaminosalicylaldehyde)diphenyl methane]diimine and its complexes with copper(II), cobalt(II), and cadmium(II). Synth React Inorg Met Org Chem 2012;42:1-8.

12. Jamuna K, Naik BR, Sreenu B, Seshaiah K. Synthesis, characterization and antibacterial activity of $\mathrm{Cu}$ (II) and $\mathrm{Fe}(\mathrm{III})$ complexes of a new tridentate schiff base ligand. J Chem Pharm Res 2012;4:4275-82.

13. Kelode SR. Synthesis, characterization and antimicrobial activity $\mathrm{Cr}(\mathrm{III}), \mathrm{Mn}(\mathrm{III}), \mathrm{Fe}(\mathrm{III}), \mathrm{VO}(\mathrm{IV}), \mathrm{Zr}(\mathrm{IV})$ and $\mathrm{UO}_{2}$ (VI) metal complexes derived from bidentate thiazole schiff base. J Chem Pharm Res 2013;5:100-3.

14. Ejidike IP, Ajibade PA. Synthesis, spectroscopic, antibacterial and free radical scavenging studies of $\mathrm{Cu}(\mathrm{II}), \mathrm{Ni}(\mathrm{II}), \mathrm{Zn}(\mathrm{II})$ and $\mathrm{Co}(\mathrm{II})$ complexes of 4,4'-\{ethane-1,2-diylbis[nitrilo(1E)eth-1-yl-1ylidene]\}dibenzene-1,3-diol Schiff base. J Pharm Sci Res 2017;9:593-600.

15. Pouralimardan $\mathrm{O}$, Anne-Christine $\mathrm{C}$, Janiak C, Hosseinimonfared H. Hydrazone Schiff base manganese(II) complexes: Synthesis, crystal structure and catalytic reactivity. Inorg Chim Acta 2007;360:1599-608.

16. Onal Z, Yildirim I, Kandemirli F, Arslan T. Experimental and theoretical studies on the reactions of 1-amino-5-benzoyl-4phenyl-1H-pyrimidine-2-one/-thione compounds with ethyl acetoacetate. J Struct Chem 2010;21:809-16.

17. Al-Shaalan NH. Synthesis, characterization and biological activities of $\mathrm{Cu}(\mathrm{II}), \mathrm{Co}(\mathrm{II}), \mathrm{Mn}(\mathrm{II}), \mathrm{Fe}(\mathrm{II})$, and $\mathrm{UO}_{2}$ (VI) complexes with a new schiff base Hydrazone: 0 Hydroxyacetophenone-7-chloro-4-quinoline Hydrazone. Molecules 2011;16:8629-45.

18. Abdel-Rahman LH, Ismail NM, Ismael M, Abu-Dief AM, Ahmed EA. Synthesis, characterization, DFT calculations and biological studies of $\mathrm{Mn}(\mathrm{II}), \mathrm{Fe}(\mathrm{II}), \mathrm{Co}(\mathrm{II})$ and $\mathrm{Cd}(\mathrm{II})$ complexes based on a tetradentate ONNO donor schiff base ligand. J Mol Struct 2017;1134:851-62.

19. Annapure SR. Synthesis and characterization of $\mathrm{Ni}(\mathrm{II}), \mathrm{Cu}(\mathrm{II})$ metal complexes of new tetradentate ligand derived from dehydroacetic acid. Int J Chemtech Res 2017;10:455-60.

20. Thakar AS, Joshi KT. Synthesis, characterization and antibacterial activity of Schiff bases and their metal complexes derived from 4-acyl-1-phenyl-3-methyl-2-pyrazolin-5-ones. J Chem 2010;7:1396-406.

21. Manjula B, Antony SA, Dhanaraj CJ. Synthesis, spectral characterization, and antimicrobial activities of Schiff base complexes derived from 4-Aminoantipyrine. [Spectrosc Lett 2014;47:518-26.

22. Makhijani RM, Barhate VD. Synthesis, characterization, and study of microbiological activity of some transition metal ion complexes with [N-(O-methoxy benzaldehyde)-2aminophenol] (NOMBAP). Int J Curr Pharm Res 2014;6:26-30.

23. Budhwani S, Sharma S, Kalyane N. Synthesis of aryl (5substituted benzofuran-2-yl) carbamate derivatives as antimicrobial agents. Asian J Pharm Clin Res 2017;10:377-81. 